\title{
Carrots, sticks, and insurgent targeting of civilians
}

\author{
Version accepted at Journal of Conflict Resolution
}

2018

Victor Asal, University at Albany, SUNY

Brian J. Phillips, corresponding author, Centro de Investigación y Docencia Económicas

(CIDE)

R. Karl Rethemeyer, University at Albany, SUNY

Corina Simonelli, University of Michigan

Joseph K. Young, American University

\begin{abstract}
How do conciliatory and coercive counterinsurgency tactics affect militant group violence against civilians? Scholars of civil war increasingly seek to understand intentional civilian targeting, often referred to as terrorism. Extant research emphasizes group weakness, or general state attributes such as regime type. We focus on terrorism as violent communication, and as a response to government actions. State tactics toward groups, carrots and sticks, should be important for explaining insurgent terror. We test the argument using new data on terrorism by insurgent groups, with many time-varying variables, covering 1998 through 2012. Results suggest government coercion against a group is associated with subsequent terrorism by that group. However, this is only the case for larger insurgent groups, which raises questions about the notion of terrorism as a weapon of the weak. Carrots are often negatively related to group terrorism. Other factors associated with insurgent terrorism include holding territory, ethnic motivation, and social service provision.
\end{abstract}

Note:

This material is based upon work supported by the Science and Technology directorate of the U.S. Department of Homeland Security under Grant Award Numbers N00140510629 and 2008-ST-061-ST0004, made to the National Consortium for the Study of Terrorism and Responses to Terrorism (START, www.start.umd.edu). The views and conclusions contained in this document are those of the authors and should not be interpreted as necessarily representing the official policies, either expressed or implied, of the U.S. Department of Homeland Security or START. 


\section{Introduction}

How do counterinsurgency tactics affect militant group violence? More specifically, how do conciliatory and coercive government tactics affect militant group violence against civilians? A great deal of research seeks to understand the consequences of counterinsurgency (e.g., Paul, Clarke, and Grill 2010), but much of this literature looks at one specific tactic, such as leadership removal (Jordan 2014, Johnston 2012) or indiscriminate targeting (Lyall 2009). Some case studies suggest that conciliatory and coercive tactics have distinct effects on insurgent violence (e.g., Dugan and Chenoweth 2012), but such research is rare. Furthermore, we do not know if relationships found in specific cases are more broadly applicable.

At the same time, civil conflict scholars increasingly seek to understand rebel violence against civilians, which is sometimes referred to as terrorism (Stanton 2013; Thomas 2014; Fortna 2015). The literature provides contrasting and incomplete explanations for this behavior. Some research suggests that rebels in democratic countries are more likely to target civilians (Hultman 2012, Stanton 2013). However, state attributes alone are unlikely to completely explain insurgent targeting. Other work finds group weakness is key to explaining civilian victimization (Wood 2010), but terrorism happens for many distinct reasons (Kydd and Walter 2006). Furthermore, some rebel groups such as the Taliban or Boko Haram are relatively strong, yet often use terrorism. What else could explain civilian targeting? Given the research on counterinsurgency tactics, it is likely that state actions contribute to rebels' targeting decisions in important ways.

To understand how government conciliation and coercion affect insurgent violence against civilians, we present an argument that draws on rationalist understandings of terrorism (Lake 2002; Kydd and Walter 2006), rooted in the assumption that terrorism is 
violent communication (Schmid and de Graaf 1982). This notion, which has a considerable history in the terrorism literature, should also be applicable to the terrorism that occurs during civil conflicts. We contend that government actions, both carrots (conciliatory tactics) and sticks (coercive tactics), affect civilian targeting as rebel groups seek to signal their responses. We argue that carrots should be associated with less terrorism, contrary to some arguments in the literature, while sticks should lead to more terrorism. We further hypothesize that group strength matters, but not in a way that is often argued: sticks should only lead to more terrorism in groups strong enough to withstand repression.

This research differs from previous work on civilian targeting by insurgent groups in several ways. First, the notion of terrorism as communication or signaling, the basis of our argument, is often overlooked in the civil war literature. Incorporating terrorism theory into the study of civil conflict is important because arguably most terrorism occurs within civil conflicts (Findley and Young 2012). Second, our focus on government counterinsurgency encompasses state-group dynamics that usually are not explicitly modelled in extant work on rebel group terrorism. A great deal of research studies how repression affects insurgents (e.g., Lyall 2009), and less work looks at the effects of concessions (Walter 2006, Dugan and Chenoweth 2012). It is rare to compare these two types of policies side by side. ${ }^{1}$ Third, our empirical approach, with new time-varying group-level data, allows us to examine relationships in ways that were not previously possible.

In the second section, we discuss the literature on civil war civilian targeting. We then describe the idea of terrorism as communication and use this framework to explain how certain counterinsurgency tactics should affect the likelihood of civilian targeting by rebels. The third section introduces new group-year data on 140 insurgent organizations, 
1998-2012. Quantitative analyses suggest government coercion against a group is associated with subsequent terrorism by that group. Additional tests suggest the relationship between sticks and rebel terrorism only exists for groups with at least 1,000 members, which is about 70 percent of the groups in the sample. This is consistent with our signaling mechanism and challenges the weapon of the weak argument. There is also some evidence that the use of carrots is associated with a reduced likelihood of subsequent terrorism. Other factors associated with rebel group terrorism include holding territory, ethnic motivation, and social service provision. Many independent variables are analyzed globally using time-varying data for the first time. We conclude with implications for the study of civilian targeting in civil conflict more broadly.

\section{Terrorism, civil conflict communication, and responses to counterinsurgency}

Terrorism has many definitions, but it is often described as violence by non-state actors used to strike fear into a wider audience for a political or social goal (e.g., Enders and Sandler 2011). Many definitions specify that the victims of terrorism are civilians or non-combatants (e.g., Asal et al. 2012). Other studies of intentional civilian victimization by rebels use the term terrorism for this violence (Stanton 2013; Thomas 2014; Fortna 2015), so we follow this practice. ${ }^{2}$

The burgeoning literature on civilian victimization during war explores regime characteristics (Eck and Hultman 2007; Hultman 2012; Stanton 2013), rebel group attributes (Wood 2010), and inter-rebel dynamics (Wood and Kathman 2015). Civil wars in democracies are particularly prone to rebel targeting of civilians (Hultman 2012; Stanton 2013). These governments are uniquely accountable to the wellbeing of civilians and may be coerced into conciliatory actions to protect the public (Hultman 2012; Pape 2003; 
Stanton 2013). At the organizational level, terrorism has been portrayed as a tactic of the weak (Hultman 2007; Polo and Gleditsch 2016; Wood 2010). Civilian targets are soft targets, easier to attack than security forces. Weak organizations' coercive measures seek to deter civilians from collaborating with the government, and the relationship is found to be stronger as the government uses more violence (Wood 2010).

Other work has shown that resource-rich groups are more likely to target local populations if they do not rely upon them for support. For example, organizations that receive foreign funding are more likely to employ violence against civilians (Weinstein 2006; Wood 2010; Salehyan, Siroky and Wood 2014). Weinstein (2006) argues that having alternative sources of funding, such as lootable resources or foreign sponsors, diminishes the importance of winning the support of local populations and their resources.

This work is important, but it often downplays interactions between rebel groups and other actors such as the state (Lapan and Sandler 1993; Bueno de Mesquita and Dickson 2007). ${ }^{3}$ By contrast, a great deal of research on terrorism emphasizes that terrorism is communication, signaling, or propaganda (Schmid and de Graaf 1982; Kydd and Walter 2006). Regarding empirical analyses, the extant literature has perhaps not focused on many organizational attributes because of data limitations at the time. One article, for example, uses civil wars as its unit of analysis, examining 95 observations, and therefore not analyzing organizational factors (Stanton 2013). Other studies, with more fine-gained units of analysis, only use a few measures of rebel group attributes (Hultman 2007; Wood 2010). The new data presented in this paper permits us to take a closer look at theoretically important characteristics of rebel organizations. 
Terrorism is a violent form of communication intended to spread a message beyond its direct victims (Crenshaw 1981; Schmid and de Graaf 1982; Walter and Kydd 2006). Groups and individuals use this tactic to signal their power, resolve, or trustworthiness to local civilians, other rebel groups, domestic and foreign governments, and international media outlets (Walter and Kydd 2006; Bapat 2012). This tactic has been deployed to provoke government violence, gain attention for a group's cause, and further tangible or spiritual objectives. However, in civil wars, rebels have already brought attention to their cause and demonstrated enough prowess to provoke a war. How does terrorism as a communicative tool work in this context?

Most models assume rebel groups seek to communicate with the government and public regarding dynamics of the conflict (e.g., Siquiera and Sandler 2006). This communication is often about demonstrating the group's relevance or territorial control. From press releases and flyers to Twitter and online propaganda, rebels strive to disseminate their messages. However, communication can be cheap talk. For rebels to offer more convincing messages, they need to send costly signals. Attacking civilians is one form of such signaling (Kydd and Walter 2006), and one that, at least in theory, any rebel group can carry out. As Kydd and Walter (2006) suggest, a group's use of terrorism may depend on who the group is targeting and whether there is uncertainty over the power, resolve, or trustworthiness of the group.

Insurgents often rely heavily on civilian populations. In some cases, their survival is predicated on their ability to diffuse into the broader population. Resource-rich civilians are a focal point of government and rebel strategies (Kalyvas 2006). Valuable civilian-held resources include food, funding, sanctuary, future recruits, and intelligence. This last resource, strategic information, has been the focus of most studies into these interactions 
(Berman and Matanock 2015). Local populations may have knowledge of whom among them are rebels or sympathetic to the rebellion. Civilians also know the local terrain; groups may try to mobilize civilians to gain a knowledge advantage.

While civilians may be predisposed to favor one side for ideological or practical reasons, these preferences evolve in response to government and rebel actions. Given the strategic importance of local support, civilian targeting is not simply a tool to pressure the government or a soft target for weak groups. Rebels actively seek to coerce the compliance or win the support of civilians. These actions do not occur in a vacuum; rebels are competing with government forces for popular support. Rebels interpret the actions of governments and signal their responses through the use or avoidance of violence. To further explore rebel use of this tactic, we must understand the government signals to which they are responding.

\section{Government actions: carrots and sticks}

Many studies of civil conflict behavior look at relatively static explanatory factors: state capacity, regime type, poverty, or rebel group resources. However, given research on counterinsurgency outcomes (e.g., Paul, Clarke, and Grill 2010; Johnston 2012), it seems likely that specific state actions also have important consequences for insurgent terrorism as well. There are two generic types of state policies toward armed groups: conciliatory or coercive. These are referred to as carrot or stick policies. This discussion refers to actions toward specific groups and not state-wide phenomena, such as regime type or the country's total number of human rights violations. ${ }^{4}$ However, just as rebel actions are costly, so are state actions. Within a rationalist framework (Lake 2002; Kydd and Walter 2006), signaling and strategic actions are important to understand for all sides of a conflict. While others 
have examined state capacity and its impact on civil war dynamics (Fearon and Laitin 2003) or terrorism (Hendrix and Young 2014), we are interested in the strategic choices made by states and rebels.

Governments have several conciliatory choices, including negotiations, concessions, or ceasefires, to offer as incentives for rebel groups to forgo violence. The effects of conciliation seem straightforward: in exchange for incentives, rebel groups should change their behavior, including reducing or ceasing civilian targeting. For example, the Revolutionary Armed Forces of Colombia (FARC), which uses a great deal of violence against civilians, has at times stopped or reduced its use of violence when the government offered concessions. ${ }^{5}$ Government conciliatory actions, such as concessions, are crucial for rebel groups as they attempt to win and maintain the support of the public. If they receive concessions from the government, this suggests to the public that the group is strong and can achieve at least some of its goals.

To receive concessions or negotiate, rebels must credibly commit to peaceful behavior. Conciliatory actions by the state signal the government's cooperative intentions and rebels respond in kind. As a result, the group is likely to refrain from violence, including targeting civilians. ${ }^{6}$ It is crucial that rebel groups demonstrate to the government their ability to control violence during negotiations, or else the government will not view the rebel group as a worthy negotiating partner (Kydd and Walter 2002). In this sense, a group that keeps its members from carrying out spoiler violence, such as terrorism, is sending a valuable signal to the government. This is also a valuable signal to the public, which is likely (especially in democratic societies) to hold the government accountable if it rewards groups that go on to use terrorism. This was demonstrated in Colombia when a 2016 public referendum temporarily imperiled a peace deal in part because citizens felt the 
FARC was not punished for their use of terrorism and would not uphold their promises of non-violence (BBC 2016). The public is likely to view a group more favorably if it can credibly control its members and deliver on promises.

Some research suggests that conciliatory measures increase the likelihood of spoiler behavior, such as civilian targeting (Bueno de Mesquita 2005). This may be accurate, but it is often by other, more extreme groups and not the group involved in negotiations. For example, when the Provisional Irish Republican Army (PIRA) began negotiations with the British government, it was not the PIRA that increased its violence. Instead, a new group, the Real Irish Republican Army (RIRA), split off the PIRA. More extreme and "pure," the RIRA used terrorism to sabotage the peace. Given the benefits of ceasefires and political negotiations, groups are highly incentivized to keep the peace, signaling their accountability to government actors and legitimacy to civilian populations. As a result, we expect that conciliatory actions achieve their desired effect: convincing groups to give up violence, particularly violence against civilians. This suggests the following hypothesis: Hypothesis 1: Rebel groups targeted with conciliatory actions (carrots) by governments should be less likely than other groups to intentionally target civilians.

Coercive actions - use of sticks - such as arrests of members or military offensives against the group, are generally intended to reduce violence. ${ }^{7}$ This might occur in two ways. First, state actions may remove insurgents from the battlefield, making them unable to perpetrate future acts. Second, the state's punitive response is meant to deter future would-be rebels. ${ }^{8}$ However, there are reasons to expect that these tactics may not achieve the intended goal and might even lead to more violence (Lake 2002; Moore 1998; Young 2013). On the one hand, states that use violence may help to enable rebel groups by turning civilians away from the government. States may no longer look like credible partners for 
peace, so civilians support the rebels, allowing the rebels to capture all the benefits of strong ties to civilians mentioned before. On the other hand, use of sticks may goad rebel groups into using especially heinous types of violence, such as intentional civilian targeting. Indeed, some studies suggest that country-wide human rights violations are associated with rebel group terrorism (Polo and Gleditsch 2016), and this is consistent with overall work on the backlash effect of repression (Walsh and Piazza 2010), but there is less quantitative analysis of repression against specific groups.

The use of coercion against rebels is not constant throughout time. There are stalemates and periods of relative calm. Many states may simply not have the resources to consistently engage rebel groups in their territory. Furthermore, governments facing multiple rebel groups might choose to engage one rebel group over another (Cunningham 2011). As a result, government coercive activity is a phenomenon with interesting variation over time and across insurgent groups in the same country.

Rebels may correctly or erroneously interpret successful counterterrorism offensives as signs that locals are abetting government forces. As previously discussed, civilian-held information about rebel members and locations can aid government forces in conducting coercive actions. When such an attack occurs, the group has three primary responses: forgo a violent response, strike a traditional military target, or attack softer civilian targets. Military targets are generally more difficult to strike than civilian targets, such as a busy market. Additionally, attacks on military targets do little to deter future coordination between civilians and government forces - which can be integral to future government operations.

By responding to government coercion by directly targeting civilians, rebels effectively signal to both the government and public simultaneously. The attack shows their 
continued ability to strike and intimidate the government's constituents. This may increase public pressure on the government to end the conflict, particularly in democratic countries. Additionally, attacking civilians is a reminder to the public that potential coordination with the government is costly.

Given that insurgents ultimately want public support, why would they attack civilians? Some civilians are viewed as pro-government or "complicitous" (Goodwin 2006), depending on factors such as their income or their ethnic group. Rebels might attack these civilians without losing their support among other members of the public. Beyond trying to win hearts and minds, rebels also seek public support coercively, and civilian targeting is consistent with this. Overall, when the state represses insurgents, they face various options, and civilian targeting is a likely response. This suggests the following hypothesis:

Hypothesis 2: Rebel groups targeted with coercive actions (sticks) by governments should be more likely than other groups to intentionally target civilians.

The relationship between state coercion and terrorism could work in both directions. There are theoretical reasons to believe that terrorism could lead to state crackdowns, and there is evidence of this. For example, Piazza and Walsh (2009) find that transnational terrorism leads to increases in certain kinds of repression. However, this does not mean that the reverse is not true as well. Theory suggests both possibilities are likely. Empirical tests can help sort out if there is, indeed, a relationship between government coercion and groups' later use of civilian targeting.

In addition to a direct relationship between repression and rebel terrorism, we suggest that the impact of state coercive actions on rebel groups is likely to be conditional on rebel group capabilities. Some groups are much stronger than others, and this is 
important because state repression could crush certain groups into submission, or at least substantially reduce their ability to respond with violence. Even though terrorism is described as a weapon of the weak, it still requires some capabilities. Thus sticks should be more likely to result in rebel group terrorism when the rebel group is strong enough to withstand the coercion and carry out its own violence in the future.

This conditional argument is important because it emphasizes that terrorism by insurgents is communication or signaling, and not an indicator of lack of group capacity. If group weakness explained terrorism, we might expect repression to lead to terrorism especially for groups that had already been less powerful. However, we argue that groups need a certain degree of capacity to carry out terrorism, especially when targeted by the state. To summarize:

Hypothesis 3: The impact of state coercive actions on rebel groups' likelihood of intentionally targeting civilians is conditional on the strength of the rebel group.

\section{Research Design}

\section{Dataset}

This manuscript introduces a new dataset of 140 insurgent groups from across the globe, examined between 1998 and 2012. ${ }^{9}$ The inclusion criteria for the dataset is based on the Uppsala Conflict Database Program (UCDP) battle deaths dataset. Our dataset is novel for its organization-year unit of analysis - including years when the group was not actively involved in conflict — and inclusion of all groups listed in UCDP regardless of their identities and ideologies. ${ }^{10}$ This data structure allows us to investigate changes to group attributes and tactics over time. The modal time groups are in the data is 14 years. We will 
first describe the creation of the actor list before discussing the individual variables included in the dataset in more detail.

The initial list included organizations that passed a threshold of 25 battle-related fatalities in any year. If the group was included in UCDP for any year in that timeframe, it was coded for the entire period. ${ }^{11}$ This initial actor list was then condensed based on the following exclusion criteria: 1) the non-government side of the conflict was listed as a generic group (such as "Syrian insurgents"). We were unable to link these incidents to specific groups and did not want to make inferences about the organization responsible; 2) the second side of the conflict was a recognized state. The UCDP battle deaths dataset is specific to intrastate conflicts, but occasionally the challenger listed is a government. For example, the data includes several years of conflict between the governments of India and Pakistan over Kashmir. These cases were excluded as we are interested in the dynamics that inform government and non-state actor relations. After these two criteria were satisfied, 158 groups remained. However, for 18 groups there was insufficient information to produce a full profile coding, so these groups were excluded.

Not all groups were active for that entire period of 1998-2012. If a group was founded in 1998 or before, 1998 is the first year of coding. We began coding groups that were founded after 1998 in the first year that any information could be found about them or their behaviors. This did not always correspond to the first year they appeared in UCDP. In many cases, we found documentation of their initiation and activities several years prior. Most groups are coded through 2012. We ceased coding groups before 2012 if any of the following occurred: 1) They disbanded and remained so through 2012. This excludes groups that issued statements of surrender or agreements to disband but evidence shows their continued existence or official resumption of activities years later. 2) They were 
integrated into the government and ceased to operate as an insurgent group. Generally, this is the result of a negotiated peace agreement that includes power sharing provisions. 3) The group transitioned to a non-violent, legal organization and remained so for all subsequent years. If the group perpetrated violence documented either in the GTD or UCDP their coding will include their "peaceful" years. 4) No further information could be found about the group. For example, if the last information about the group was in 2000, rather than coding 2001-2012 as all unknown values, we would cease coding the group in 2001 and note that no further information could be found.

\section{Variables}

Descriptive data for the variables used in the study are presented in Table 1 . The dependent variable, Terrorism, is a dichotomous variable derived from the Global Terrorism Database (GTD). This source is probably the most widely used database of terrorist attacks. The GTD (2016) uses a rather broad definition of terrorist attack: "the threatened or actual use of illegal force and violence by a non-state actor to attain a political, economic, religious, or social goal through fear, coercion, or intimidation." Given the wide-ranging nature of this definition, we exclude attacks against military and police targets, for a more precise measurement of terrorism. Therefore, the dependent variable was created from a count of all terrorist attacks against civilian targets recorded in the GTD for a given organization.

If a group, according to the GTD, conducts at least one attack on a civilian target, it was coded 1 for that year. If the group did not conduct attacks, or solely attacked military or police targets, Terrorism was coded zero for that year. Interestingly, only a minority of the group-years, about $40 \%$, are coded 1 for terrorism. This type of variation is one of the 
reasons we use a dichotomous dependent variable instead of a count dependent variable (though we have also modeled terrorist attack counts - see below). The key variation seems to be between whether a group uses terror or not, instead of how many acts a group launches in a year. Relatedly, we are more confident that the GTD correctly identifies the groups using terrorism than in the accuracy of every recorded attack. We also created a lead version of Terrorism. For this we used, for example, the 2005 value of the dependent variable paired with the values of the independent variables for 2004. We used this type of dependent variable for some models to reduce the likelihood of reverse causality. This is the same as using lagged versions of all time-varying independent variables.

As a robustness check, we also report the results of count models where the dependent variable is the count of terrorist attacks GTD attributes to the group (again excluding military or police targets) in a year. An alternative dependent variable, the UCDP indicator of one-sided deaths perpetrated by rebel groups, is shown in the appendix. This UCDP variable has a higher threshold for inclusion, as it only is coded for one-sided violence when there are at least 25 deaths due to such violence per year. We prefer our more fine-grained measure of non-combatant targeting by rebel groups as our primary measure, but discuss results using the UCDP measure as well.

[Table 1 about here.]

Table 1 provides summary statistics for each variable. Unless otherwise noted, data for all independent variables was gathered by our research team. An important advantage of our dataset over others is that most variables potentially change each year, as opposed to being the same value for all years. To find such fine-grained yearly information, more than two dozen coders over multiple years searched academic and journalistic sources for 
information about specific groups. LexisNexis was a key source, where our coders would conduct guided searches based on rebel group names, aliases, and all related spelling variations. Coding supervisors would then check the information of coders against each other and make final decisions.

To test hypothesis 1 and hypothesis 2 , we included measures of the domestic and international counterterrorism or counterinsurgency tactics used against the groups. These variables come from a summary of the actions by all actors (excluding non-state groups) countering the insurgent, including the domestic government, foreign governments, and intergovernmental institutions (such as the North Atlantic Treaty Organization, International Criminal Police Organization, African Union, etc.). The variables measure discriminate targeting of insurgent groups. While the counterterrorism strategy may be broad enough to affect civilian populations intentionally or accidentally, the coding requires evidence that the tactic was specifically used against group members or the organization broadly. This offers more refinement than counterterrorism measures at the country-level that code general policies.

These actions can be categorized as carrot, stick, or mixed carrot and stick. Carrot tactics are conciliatory in nature and include negotiations, ceasefires, incentive programs, and concessions to the group's demands. Dugan and Chenoweth (2012) measure Israeli counterterrorism actions against Palestinian insurgents and include social service provision, peace talks, withdrawal of troops, and release of Palestinian prisoners as carrot actions. When Israel engaged in more of these actions, specifically during the Oslo Accords, terrorist violence was most effectively reduced.

Stick tactics are repressive or punitive tactics that make use of any police, military, intelligence, or judicial mechanisms to counter the group. This variable includes measures 
as extensive as the United States' military operations in Afghanistan against Al-Qa'ida and the Taliban after $9 / 11$ and as minor as the arrest of a single member of the insurgency. Some research suggests that stick measures are more common when an insurgency is in its infancy and governments only consider carrots, such as peace negotiations, when the organization has become a considerable security threat (Bapat 2005, 2006). While other work (e.g., Jones and Libicki 2008) has sought to link counterterrorism policy to group demise, our data shows that most groups persist into the next year regardless of variation in counterterrorism policy. In 2012, our last year of available data, $76 \%$ of all the groups in our data still existed even after applying the termination criteria described earlier.

To test hypothesis three, we use an interaction of Stick and a group membership size variable, because group size is often used as a proxy for strength (Jones and Libicki 2008). Organizational size is determined based on reports of the group's number of members for each year. Groups were coded from 1 to 4 with 1 representing groups with less than 100 members, 2 indicating 100-999, 3 meaning 1,000 to 9,999, and 4 representing groups with greater than 10,000. In instances where the size was unknown, the group was coded for the lowest possible value. An exact value, range, or approximation was also included as the dataset as a strength variable, but strength was not used in the analysis. If divergent size estimations were found from equally valid sources within one year, the smaller approximation was used. Categorical size variables are commonly used because precise numbers are difficult to estimate for most clandestine groups (e.g., Jones and Libicki 2008). Unlike in other datasets, the size variables may change yearly in our data.

Regarding control variables, we also include a measure called Mixed if both stick and carrot tactics are used against the group within one year. For instance, even when Israel engaged in numerous conciliatory actions and peace negotiations, they continued to employ 
repressive measures to rebuff terrorist attacks (Dugan and Chenoweth 2012). Mixed codings include a domestic government that simultaneously employs both tactics and cases in which one counterterrorism actor consistently uses one tactic while another actor uses the other tactic. While we hypothesize relationships for carrot and stick, we are agnostic about the expected relationship between mixed government strategies and rebel group actions but include it as an important control.

We include Territory as another control variable. For militant groups to maintain their control of territory, they need compliance from the civilians living there, and this is often achieved through coercion (Kalyvas 2006; Mampilly 2011,8). Groups controlling territory might attack civilians to send a signal to the public in their area that compliance is mandatory - to encourage civilians to give information to them, and not the government. Territorial control was determined yearly. A group was coded as controlling territory if it had the ability to control movement into, out of, and within a specific region. This included areas controlled by the threat or use of force or territories held because of an election or with governmental approval. To be classified as a territory, the area must be substantial, such as a city or region, and does not include buildings or a city block. In cases where a group took over a city and then were routed by government forces within days or weeks, the group was not coded as controlling territory for that year unless they held other territory or were able to sustain control at a later date.

We include measures of group alliances and rivalry. Inter-organizational alliances can provide groups with resources to carry out terrorism (Asal and Rethemeyer 2008, Bacon 2014, Phillips 2014), while intergroup competition often has deleterious consequences for civilians as militant groups use terror to signal their prowess or resolve (Bloom 2005; Conrad and Greene 2015; Metelits 2009; Nemeth 2013). For these variables, 
information was compiled into a dyadic network that included other insurgent organizations active in that year. We then calculated several measures of network centrality to gauge the organizations intensity of relations with other insurgent entities. Because there is not consensus on the "best" measure of network connectivity in this context, we experimented with several alternative measures. Previous research (Asal and Rethemeyer 2008; Asal, Ackerman, and Rethemeyer 2012; Horowitz and Potter 2014) demonstrates that different phenomena are better explained by different forms of centrality. Here, more sophisticated measures of network embeddedness (Granovetter 1985) provide a better fit. Alliances were measured through average reciprocal distance (ARD) and calculated using UCINET 6's "multiple centrality" command for each year. ARD is a modified form of closeness centrality; it measures the number of alliance connections but also allows for more distant alliances to count (unlike degree centrality). ARD has attractive properties for disconnected networks (see Cunningham, Everton, and Murphy 2016; Borgatti, Carley, and Krackhardt 2006).

Rivals are groups that launch attacks against each other (e.g., Phillips 2015). Here, experimentation found that Bonacich power centrality - another means of specifying network embeddedness - was found to be a better fit (Bonacich 1987); this was also calculated using UCINET 6's “multiple centrality” command for each year. Bonacich power centrality is similar to eigenvector centrality but may be "tuned" via a beta parameter. The best fit is with the largest permissible value (Bonacich 1987). It is possible for two groups to have elements of a positive and negative relationship within one year. In these cases, such as rivals Fatah and Hamas collaborating, both the rival and allied relationship are recorded. 
Ideologies were coded either 0 if not present or 1 if the group adhered to that ideology. Ideology is commonly identified as an indicator of group intentions or capacity. To capture the complexity of insurgent groups' belief systems and goals, ideology codes were not mutually exclusive nor static. A group could be coded as ethnic, religious, and leftist if its goals and rhetoric represented all those beliefs. A group was coded as ethnic if it represents an ethnic population and advocates for that population's rights. A group that espoused a religious ideology as a basis for their goals was coded religious. A group was coded as leftist if it promotes economically leftist policies such as redistribution of wealth by the government and nationalization of industry.

Regarding organizational structures of rebel groups, we focused on the nature of group leadership, defined by who in the organization determines the goals, actions, and strategies, and then how those orders are processed into actions. We use a set of dichotomous variables indicating leadership type. ${ }^{12}$ Groups that either elected or selfappointed a governing council that would vote on decisions were coded as Governing council. Some groups operated under a single leader without any deputies or lower commander where this top leader was the only person able to issue directives. These groups are coded as Single leader. The reference category is other types of leadership, such as multiple leaders or a hierarchical set of leaders under one executive with veto power. ${ }^{13}$

Social service provision has been argued to be essential in explaining terrorism by militant groups (Berman 2009). Providing such services can foster public support by signaling that the group is a viable substitute for the government. This variable is coded based on several categories of services, including club goods, medical services, welfare, educational services, religious services, infrastructure, police protection, or other additional public goods provided directly to the public without charge. If any of these services were 
provided by the group to individuals beyond the group membership, then Social services was coded 1 for that year. If the group had members in national or local government, the services provided by the government were not considered social services provided by the group.

To capture participation in electoral politics we included a variable for holding of a Legal political office by the group. This means a group operates as a political party and there is proof that members of the party hold elected positions at the local, regional, or national level. If the organization fits these criteria, we coded the variable as 1 and if not or if no information could be found, the variable was coded 0 . Once documentation of Legal political office was found, the coder assumed the seat was held through the elected term unless there was evidence the official left office or another election was held. This coding excludes groups that held elected positions under a separate political wing. To compete for office, groups must be legitimate, but terrorism is often considered illegitimate by the broader electorate and disqualifying by the government. Thus, holding office may constrain the extent to which organizations use terrorism, as these groups are trying to signal their legitimacy and should probably refrain from civilian targeting.

To determine group funding, we looked at several different methods of funding including drug trafficking, donations, extortion, abduction for ransom, robbery, smuggling, financing from other violent groups, and state sponsorship. Groups commonly used multiple tactics within a given year. For the purposes of this paper we have focused on drug trafficking. It may that involvement in the drug trade signals to the population a group's lack of credibility as an alternative to the state. If a group was found to be smuggling drugs, this was coded solely under drug trafficking and not also under smuggling. To take into consideration past group behavior, we include a variable called Terrorism history, which is 
a cumulative count of attacks attributed to the group in the GTD without military or police targets. This measure may signal to the state and population that a group is capable and willing to continue this tactic. Beyond group attributes, models include the number of battle deaths each year in the conflict (UCDP 2016), to control for broader conflict dynamics.

We also include control variables at the state-level. To code country attributes, each group was coded for a home base where the group has its organizational headquarters. For most groups this is where they conduct their operations, but some have a home base other than the location of most of their attacks. The home base is identified for every year to account for groups that shift their bases. For example, from 1998-2001 Al-Qa'ida is coded with a home base of Afghanistan, and then it was changed to Pakistan after $2001 .^{14}$

The first country control variable is State human rights violations. Walsh and Piazza (2010) find that when states use repression against their populations, terrorism is more likely. Polo and Gleditsch (2016) find that that state-wide repression is a factor in rebel use of terrorism. Human rights violations were coded based on the Amnesty International Political Terror Scale provided in the Quality of Government dataset (Teorell et al. 2016). State-sanctioned terror is coded as an ordinal measure with 1 representing no or few human rights violations and 5 meaning government use of a wide range of repressive tactics against the entire population. This measure is different from the Stick variable because the broader, state-wide human rights measure takes into consideration actions not necessarily targeting the rebel group under observation. Additionally, as noted previously, the Stick measure includes many actions that are not necessarily human rights violations, such as arrests or judicial orders. Consistent with these differences, State human rights violations is virtually uncorrelated with Stick. 
The second state-level control variable measures regime type. Numerous studies have linked democracies to increased rates of terrorism ( $\mathrm{Li} 2005)$. To code regime type, we used the Quality of Government measure that combines Freedom House and Polity data, to reduce missing data problems, which has a scale of $0-10$ where 0 is the least democratic and 10 in the most democratic. This regime type measure is uncorrelated with Carrot, Stick, or Mixed. A measure of gross domestic product per capita (GDPPC) was included to account for the relative wealth and economic development of the countries as wealthier nations have greater capacity and resources to counter or deter violence. This control is a rough proxy for state capacity, a structural alternative to our strategic choice-based explanation. This information was generated from the National Main Aggregates database maintained by the United Nations Statistics Division (available at data.un.org). A natural logarithm is used to have a more comparable coefficient. Finally, each country's logged population is included because studies have shown more populous countries experience more terrorism.

\section{Estimation}

Since our dependent variable is a binary measure of insurgent organization use of terrorism in the year in question, our primary model uses logistic regression. As an additional test, we show count models (Models 3 and 4), using negative binomial regression. To take temporal issues into consideration, models include year dummies. If a time trend (year count) variable is included instead of year fixed effects, results are robust. ${ }^{15}$ Because each group is measured repeatedly, we include group random effects to capture otherwise unmeasured group attributes (Beck 2001; Bell and Jones 2015). ${ }^{16} \mathrm{~A}$ Hausman test suggests random effects models are not systematically different from fixed 
effects models. An additional issue with fixed effects is that they cause time-invariant variables to drop out of the models.

Additional models are shown in the appendix to test the robustness of the primary models. Robustness checks feature: models with no control variables or only group control variables, two-year lags on independent variables, the alternate UCDP dependent variable rebel group one-sided violence, a lagged dependent variable, the exclusion of random effects, instrumental variables to address the potential endogeneity of key independent variables, and samples that only include groups or group-years where violence or fatalities were observed.

[Table 2 about here.]

\section{Primary results}

Table 2 includes our main regression results. Model 1 is the primary model. The coefficient associated with Carrot is negatively signed and statistically significant, suggesting that governments that use conciliatory tactics toward a rebel group are less likely to see terrorism from that group in the following year. Groups seem to refrain from terrorism to signal their trustworthiness and control over their members. This suggests support for the first hypothesis, but additional models discussed below raise some doubts about the robustness of this relationship. The coefficient associated with Stick is statistically significant and positively signed. This suggests that government repressive tactics against rebel groups are associated with an increased likelihood of the use of terrorism by those groups in the following year. This provides support for hypothesis two. 
Model 2 introduces the interaction term to test hypothesis three, which suggests that the impact of stick tactics on group terrorism depends on group strength. The coefficient on the interaction term is statistically significant and positively signed, suggesting that government coercive tactics and larger group size are jointly associated with an increased likelihood of rebel terrorism. To explain this result in a more intuitive way, Figure 1 graphs the relationship between Stick and Terrorism, conditional on Group size. The figure suggests there is a conditional relationship, consistent with the hypothesis. There is only a statistically significant relationship between Stick and Terrorism for groups with at least 1,000 members, which is about $70 \%$ of the groups in the sample. This is consistent with the idea that weaker (smaller) groups are unable to respond to coercion with terrorism. Larger groups are better equipped to withstand repression sufficiently to respond, signaling their continued relevance.

[Figure 1 about here.]

Regarding control variables in Models 1 and 2, some return expected results, while others are statistically insignificant. The coefficient on Group size in Model 1, without the interaction term, is statistically insignificant. This raises questions about notions that weaker (smaller) groups are more likely to use terrorism. While the conditional relationship exists with Stick, it does not appear that rebel group size on its own is associated with terrorism use. The coefficient for Mixed is statistically insignificant, suggesting that a combination of both policies by a government toward a rebel group is not associated with a changed likelihood of terrorism use by that group. It could be that the combined effect of repression encouraging terrorism and concessions reducing it lead to a net effect of no 
much of a change in the likelihood of terror. Many countries use such combined carrot-andstick policies, but these results suggest that contrary to countries' wishes, the combined approach is not associated with a reduced likelihood of the group using terrorism.

Territory is statistically significant and positively signed, suggesting that if a rebel group holds territory, it is much more likely to use terrorism than a group that does not hold territory. The centrality measures for alliances and rivalries are both statistically significant and positively associated with the dependent variable. Regarding group ideology, the coefficient on Ethnic group is statistically significant and positively signed, suggesting ethnically motivated groups are more likely to use terrorism than non-ethnic groups. Interestingly, the coefficient associated with Religious group is not statistically significant. This goes against some assertions that religious groups are especially violent or prone to terrorism. Leftist group and both leadership type variables are statistically insignificant, suggesting that these factors are not associated with group terrorism use.

Social services is statistically significant and positively signed, suggesting groups engaging in this behavior are more likely to use terrorism. This is consistent with the literature. It could be that social service provision, which helps groups gain recruits and support, makes groups better equipped to carry out terrorism if they so desire. The results suggest that rebel groups with a political office holder are less likely than groups without a legitimate office holder to use terrorism. This is intuitive, as groups interested in legal, nonviolent politics are likely to avoid behavior that could affect their reputation as legitimate political players. Drugs is statistically insignificant, suggesting group involvement in the drug business is not associated with terrorism use. Terrorism history is positively signed and statistically significant, as expected. 
Consistent with expectations, the measure of battle deaths in civil conflict is associated with a higher likelihood of terrorism by groups, although the coefficient is not highly significant $(p<.10)$. Interestingly, neither the country-wide measure of state humanrights violations nor the measure of regime type is statistically significant. These factors are often found to be related to terrorism in general, but the lack of result here suggests that terrorism in civil wars could have unique determinants. It also suggests the importance of looking at group-specific measures instead of state-wide measures. GDPPC is statistically significant and positively signed. One way to interpret this would be that groups in strong states are more likely to use terrorism, and this is consistent with the notion of terrorism as a tool of the (relatively) weak. However, given the roughness of the measure, and the fact that it is aggregated at the country level instead of group-specific, we should be cautious drawing inferences. Finally, State population is significant and positively signed, suggesting a greater likelihood of rebel terrorism in more populous countries.

\section{Additional models}

Table 2 includes alternative specifications of Models 1 and 2, and many more additional tests are included in the appendix. Model 3 and 4 use a count version of Terrorism. The results for Carrot and Stick are robust in Model 3, and the results of the interaction are robust in Model 4, but Carrot is only marginally significant in Model 4. The weakened significance of Carrot is consistent with some other robustness checks discussed below. Interestingly, Mixed is statistically significant in this model. Mixed carrot and stick strategies are not related to the likelihood of terrorism in general, but they are associated with additional acts of group terrorism. It could be that the goodwill of concessions is undone by some repression, leading to increases in terrorism. 
To conserve space, other robustness checks are found in the online appendix, including models: with more parsimonious independent variable sets; with additional temporal lags of independent variables; with the UCDP measure of one-sided violence by rebel groups as an alternate dependent variable; including a lagged dependent variable; excluding random effects; with a dichotomous control for any past terrorism use; and with the sample restricted to only groups or group-years where group violence or fatalities were observed. Importantly, two models also use instrumental variables to address the potential endogeneity of counterterrorism measures to group violence (e.g., Ritter and Conrad 2016). ${ }^{17}$ In most of these models, the Carrot result remains statistically significant at $p<.05$ or $p<.10$. However, the coefficient on Carrot is sometimes marginally statistically significant, and sometimes not significant at all. The Stick result is robust in the appendix models, as is the interaction term (when graphed, if not in the table). This provides strong evidence that state coercive measures toward rebel groups are associated with later terrorism by these groups - but not for smaller rebel organizations.

\section{Conclusion}

We have argued that rebels are likely to use symbolic violence to send a costly signal to the government and civilian population after state coercive actions. Using new yearly data on terrorism by rebel groups, we show that state coercive actions - sticks - are robustly associated with later rebel use of terrorism. This is particularly the case for larger rebel organizations, those with at least 1,000 members, that can withstand state repression. This finding is consistent with our signaling argument and raises questions about group capacity arguments that solely focus on terrorism as a tool of the weakest actors. These 
relationships hold when using several approaches to take into consideration the possibility of reverse causality.

There is also some, but less robust, support for the notion that state conciliatory actions are associated with a reduced likelihood of rebel terrorism in subsequent years. Rebels are likely to reduce terrorism after negotiations or concessions to signal trustworthiness and control over their members. Contrary to some arguments, we found no evidence of a positive relationship between carrot tactics and subsequent terrorism. Regarding other results, we found little support for some ideas in the conventional wisdom, such as the notion that group weakness should lead to a greater chance of terrorism. Some results were consistent with the literature, such as a greater likelihood of terrorism by groups in alliances or that provide social services.

Overall, the focus on state counterinsurgency tactics raises interesting questions. Other studies examined state violence generally (Wood 2010), or human rights violations (Walsh and Piazza 2010) in countries, but we used a measure of actions against specific groups. It would be ideal to break down specific types of tactics against groups, such as arrests vs. military raids. This is an important task for future data collection efforts. Additionally, are there other conditional relationships involving state actions against specific groups? For example, do interactions with rebels depend on whether the state is democratic or non-democratic (Daxecker and Hess 2013)?

Future research should differentiate between carrot and stick counter-terrorism and counter-insurgency policies. A great deal of conflict research overlooks specific government tactics, focusing instead on fairly static attributes such as regime type, state capacity, or poverty. State approaches toward rebel groups often vary by group and change over time. Perhaps one reason quantitative studies, at least, have not focused much on state 
policies toward rebels is a lack of reliable data. As scholars gather more data (e.g., Dugan and Chenoweth 2012), fruitful research is likely to emerge that examines both structures and dynamic interactions between states and rebels.

Beyond hypothesized relationships, the new data introduced in this paper contributes to growing research on organizational dynamics of civil war, and the importance of organizational attributes in general. Scholars have theorized about, for example, social service provision (e.g., Flanigan 2008; Berman 2009), but were not able to test hypotheses on samples of all rebel groups around the world. We found social service provision related to violence, which is consistent with some arguments (Berman 2009) but had not been found by some regional analyses (Asal and Phillips 2015). The data on rebel group inter-organizational relationships, leadership type, and involvement in drug smuggling will enable scholars to explore causes and consequences of these phenomena in ways that had not yet been possible. 


\section{Works cited}

Asal, Victor H., Gary Ackerman, and R. Karl Rethemeyer. 2012. Connections Can Be Toxic: Terrorist Organizational Factors and the Pursuit of CBRN Weapons. Studies in Conflict \& Terrorism 35(3): 229-254.

Asal, Victor, De la Calle, Luis, Findley, Michael G. and Young, Joseph K., 2012. Killing civilians or holding territory? How to think about terrorism. International Studies Review, 14(3): 475-497.

Asal, Victor, and Phillips, Brian J. 2015. What explains ethnic organizational violence? Evidence from Eastern Europe and Russia. Conflict Management and Peace Science. OnlineFirst.

Asal, Victor, and Rethemeyer, R. Karl. 2008. The nature of the beast: Organizational structures and the lethality of terrorist attacks. The Journal of Politics, 70(2), 437-449.

Bacon, Tricia, 2014. Alliance hubs: Focal points in the international terrorist landscape. Perspectives on Terrorism, 8(4).

Bapat, Navin A. 2005. Insurgency and the opening of peace processes. Journal of Peace Research 42(6): 699-717.

Bapat, Navin A., 2012. Understanding state sponsorship of militant groups. British Journal of Political Science, 42(1): 1-29.

BBC News. 2016, Oct 3. "Colombia referendum: Voters reject FARC peace deal.” http://www.bbc.com/news/world-latin-america-37537252

Beck, Nathaniel. 2001. Time-series-cross-section data: What have we learned in the past few years? Annual Review of Political Science 4(1): 271-293.

Bell, Andrew, and Kelvyn Jones. 2015. "Explaining fixed effects: Random effects modeling of time-series cross-sectional and panel data." Political Science Research and Methods 3(1): 133-153.

Berman, Eli. 2009. Radical, Religious, and Violent: The New Economics of Terrorism. Cambridge, MA: MIT Press.

Berman, Eli and Matanock, Aila. 2015. The Empiricists' Insurgency. Annual Reviews of Political Science. 18: 443-464

Bloom, Mia, 2005. Dying to kill: The allure of suicide terror. New York: Columbia University Press. 
Bonacich, Phillip. 1987. Power and Centrality: A Family of Measures. American Journal of Sociology 92(5), 1170-1182.

Borgatti, Stephen P. Kathleen M. Carley, and David Krackhardt. 2006. On the Robustness of Centrality Measures under Conditions of Imperfect Data. Social Networks 28: 124136.

Bueno de Mesquita, Ethan, 2005. Conciliation, counterterrorism, and patterns of terrorist violence. International Organization, 59 (1): 145-176.

Bueno de Mesquita, Ethan. and Dickson, Eric S. 2007. The propaganda of the deed: Terrorism, counterterrorism, and mobilization. American Journal of Political Science, 51(2): 364-381.

Conrad, Justin and Greene, Kevin, 2015. Competition, differentiation, and the severity of terrorist attacks. The Journal of Politics, 77(02): 546-561.

Crenshaw, Martha, 1981. The causes of terrorism. Comparative politics, 13(4): 379-399.

Cunningham, David, Sean Everton, and Philip Murphy. 2016. Understanding Dark Networks: A Strategic Framework for the Use of Social Network Analysis. London: Rowman \& Littlefield.

Cunningham, David, Gleditsch, Kristian and Idean Salehyan, 2009. It Takes Two: A Dyadic Analysis of Civil War Duration and Outcome? Journal of Conflict Resolution, 53(4): 570-597.

Cunningham, Kathleen G., 2011. Divide and conquer or divide and concede: How do states respond to internally divided separatists? American Political Science Review, 105(2): 275-297.

Daxecker, Ursula E., and Michael L. Hess. 2013. Repression hurts: coercive government responses and the demise of terrorist campaigns. British Journal of Political Science 43(3): 559-577.

Dugan, Laura, and Erica Chenoweth. 2012. "Moving beyond deterrence: The effectiveness of raising the expected utility of abstaining from terrorism in Israel." American Sociological Review 77(4): 597-624.

Eck, Kristine \& Hultman, Lisa 2007. One-Sided Violence Against Civilians in War: Insights from New Fatality Data. Journal of Peace Research, 44(2): 233-246.

Enders, Walter and Sandler, Todd, 2011. The political economy of terrorism. Cambridge University Press. 
Findley, Michael G. and Young, Joseph K., 2012. Terrorism and civil war: A spatial and temporal approach to a conceptual problem. Perspectives on Politics, 10(02): 285-305.

Findley, Michael G. and Young, Joseph K, 2015. Terrorism, Spoiling, and the Resolution of Civil Wars. The Journal of Politics, 77(4): 1115-1128.

Flanigan, Shawn Teresa. 2008. Nonprofit service provision by insurgent organizations: the cases of Hizballah and the Tamil Tigers. Studies in Conflict \& Terrorism 31(6): 499519.

Fortna, Virginia Paige. 2015. Do Terrorists Win? Rebels' Use of Terrorism and Civil War Outcomes. International Organizations, 69(3): 519-556.

Granovetter, Mark. 1985. Economic Action and Social Structure: The Problem of Embeddedness. American Journal of Sociology, 91(3): 481-510.

Global Terrorism Database. 2016. GTD Codebook: Inclusion Criteria and Variables. June 2016. https://www.start.umd.edu/gtd/downloads/Codebook.pdf

Goodwin, Jeff. 2006. A theory of categorical terrorism. Social Forces 84(4): 2027-2046.

Hendrix, Cullen S., and Joseph K. Young. 2014. "State capacity and terrorism: A twodimensional approach." Security Studies 23(2): 329-363.

Horowitz, M.C. and Potter, Philip B.K. 2014. Allying to kill: Terrorist intergroup cooperation and the consequences for lethality. Journal of Conflict Resolution 58 (2): 199-225.

Hultman, Lisa. 2007. Battle losses and rebel violence: Raising the costs for fighting. Terrorism and Political Violence, 19(2): 205-222.

Hultman, Lisa. 2012. Attacks on Civilians in Civil War: Targeting the Achilles Heel of Democratic Governments. International Interactions, 38(2): 164-181.

Johnston, Patrick B. 2012. Does decapitation work? Assessing the effectiveness of leadership targeting in counterinsurgency campaigns. International Security 36 (4), 47-79.

Jones, Seth G., and Libicki, Martin C. 2008. How terrorist groups end: Lessons for countering al Qa'ida. Santa Monica, CA: RAND Corporation.

Jordan, Jenna. 2014. Attacking the leader, missing the mark: Why terrorist groups survive decapitation strikes. International Security 38 (4): 7-38.

Kalyvas, Stathis. 2006. The Logic of Violence in Civil War. New York: Cambridge University Press. 
Kydd, Andrew. and Walter, Barbara .F. 2002. Sabotaging the peace: The politics of extremist violence. International Organization, 56(2): 263-296.

Kydd, Andrew. \& Walter, Barbara. 2006. The Strategies of Terrorism. International Security, 31(1): 49-80.

Lake, David A. 2002. Rational extremism: Understanding terrorism in the twenty-first century. Dialogue IO, 1(01): 15-29.

LaFree, Gary and Ackerman, Gary, 2009. The Empirical Study of Terrorism: Social and Legal Research. Annual Review of Law and Social Science, (5): 347-374.

Lapan, H.E. and Sandler, Todd, 1993. Terrorism and signaling. European Journal of Political Economy, 9(3): 383-397.

Li, Quan. 2005. Does democracy promote or reduce transnational terrorist incidents?.Journal of Conflict Resolution, 49(2): 278-297.

Lyall, Jason. 2009. Does indiscriminate violence incite insurgent attacks? Evidence from Chechnya. Journal of Conflict Resolution 53(3): 331-362.

Mampilly, Zachariah C. 2011. Rebel Rulers: Insurgent Governance and Civilian Life During War. Ithaca: Cornell University Press.

Metelits, Claire. 2009. Inside Insurgency: Violence, Civilians, and Rebel Group Behavior. New York: NYU Press.

Moore, Will H. 1998. Repression and dissent: Substitution, context, and timing. American Journal of Political Science: 851-873.

Moore, Will H. 2000. The repression of dissent: A substitution model of government coercion. Journal of conflict resolution 44(1): 107-127.

Nemeth, Stephen. 2013. The Effect of Competition on Terrorist Group Operations. Journal of Conflict Resolution, 58(2): 336-362.

Paul, Christopher, Clarke, Colin P. and Grill, Beth, 2010. Victory has a thousand fathers: Sources of success in counterinsurgency. Santa Monica: Rand Corporation.

Phillips, Brian J. 2014. Terrorist group cooperation and longevity. International Studies Quarterly 58 (2): 336-347.

Phillips, Brian J. 2015. Enemies with benefits? Violent rivalry and terrorist group longevity. Journal of Peace Research 52 (1): 62-75. 
Piazza, James A., and James Igoe Walsh. 2009. Transnational terror and human rights. International Studies Quarterly 53(1): 125-148.

Polo, Sara MT, and Kristian Skrede Gleditsch. 2016. Twisting Arms and Sending Messages: Terrorist Tactics in Civil War. Journal of Peace Research (53)6: 815-829.

Rasler, Karen. 1996. Concessions, repression, and political protest in the Iranian revolution. American Sociological Review, 132-152.

Ritter, Emily Hencken, and Courtenay R. Conrad. 2016. Preventing and responding to dissent: The observational challenges of explaining strategic repression. American Political Science Review 110(1): 85-99.

Salehyan, Idean, Siroky, David, and Wood, Reed M. 2014. External rebel sponsorship and civilian abuse: A principal-agent analysis of wartime atrocities. International Organization, 68(03): 633-661.

Schmid, Alex P. and De Graaf, Janny. 1982. Violence as communication: Insurgent terrorism and the Western news media. London: Sage.

Siqueira, Kevin and Sandler, Todd. 2006. Terrorists versus the government strategic interaction, support, and sponsorship. Journal of Conflict Resolution, 50(6): 878-898.

Stanton, Jessica. 2013. Terrorism in the Context of Civil War. Journal of Politics, 75(4): $1009-1022$.

Teorell, Jan, Stefan Dahlberg, Sören Holmberg, Bo Rothstein, Anna Khomenko \& Richard Svensson. 2016. The Quality of Government Standard Dataset, version Jan16. University of Gothenburg: The Quality of Government Institute, http://www.qog.pol.gu.se doi:10.18157/QoGStdJan16

Thomas, Jakana. 2014. Rewarding bad behavior: How governments respond to terrorism in civil war. American Journal of Political Science, 58(4): 804-818.

UCDP Battle-Related Deaths Dataset v.5-2016, Uppsala Conflict Data Program, www.ucdp.uu.se, Uppsala University.

Walsh, James I., and James A. Piazza. 2010. Why Respecting Physical Integrity Rights Reduces Terrorism. Comparative Political Studies 43 (5): 551-577.

Walter, Barbara F. 2006. Information, uncertainty, and the decision to secede. International Organization 60 (1): 105-135.

Weinstein, Jeremy M. 2006. Inside Rebellion: The Politics of Insurgent Violence. Cambridge: Cambridge University Press. 
Wood, Reed M. 2010. Rebel capability and strategic violence against civilians. Journal of Peace Research, 47(5): 601-614.

Wood, Reed M. and Kathman, Jacob D. 2015. Competing for the Crown: Inter-rebel Competition and Civilian Targeting in Civil War. Political Research Quarterly, 68(1): 167-179.

Young, Joseph K., 2013. Repression, Dissent, and the Onset of Civil War. Political Research Quarterly, 66(3): 516-532. 
Table 1. Descriptive data

\begin{tabular}{lcclll}
\hline Variable & Obs. & Mean & Std. dev. & Min. & Max. \\
\hline Terrorism & 1,386 & 0.396 & 0.489 & 0 & 1 \\
Carrot & 1,386 & 0.042 & 0.200 & 0 & 1 \\
Stick & 1,386 & 0.452 & 0.498 & 0 & 1 \\
Group size & 1,386 & 2.688 & 0.705 & 1 & 4 \\
Mixed & 1,386 & 0.234 & 0.424 & 0 & 1 \\
Territory & 1,386 & 0.247 & 0.431 & 0 & 1 \\
Alliances (ARD) & 1,386 & 1.758 & 3.071 & 0 & 17.5 \\
Rivalry (Bonacich centrality) & 1,386 & 21.140 & 88.036 & 0 & 672.18 \\
Ethnic group & 1,386 & 0.543 & 0.498 & 0 & 1 \\
Religious group & 1,386 & 0.346 & 0.476 & 0 & 1 \\
Leftist group & 1,386 & 0.212 & 0.409 & 0 & 1 \\
Group size & 1,386 & 2.688 & 0.705 & 1 & 4 \\
Governing council & 1,386 & 0.134 & 0.341 & 0 & 1 \\
Single leader & 1,386 & 0.058 & 0.233 & 0 & 1 \\
Social services & 1,386 & 0.098 & 0.298 & 0 & 1 \\
Legal political office & 1,386 & 0.076 & 0.265 & 0 & 1 \\
Drugs & 1,386 & 0.128 & 0.334 & 0 & 1 \\
Terrorism history & 1,386 & 33.089 & 104.397 & 0 & 1,481 \\
Conflict battle deaths & 1,386 & 219.328 & 825.214 & 0 & 14,716 \\
State human rights violations & 1,386 & 4.038 & 0.896 & 1 & 5 \\
State regime type & 1,386 & 5.071 & 2.840 & 0.250 & 10 \\
State GDPPC (log) & 1,386 & 6.726 & 1.099 & 4.151 & 10.791 \\
State population (log) & 1,386 & 17.705 & 1.633 & 13.459 & 20.936 \\
\hline
\end{tabular}


Table 2. Rebel group terrorism in civil wars, 1998-2012.

\begin{tabular}{|c|c|c|c|c|}
\hline & $\begin{array}{c}\text { Model } 1 \\
\text { Primary model }\end{array}$ & $\begin{array}{c}\text { Model } 2 \\
\text { Primary } \\
\text { interaction model }\end{array}$ & $\begin{array}{c}\text { Model } 3 \\
\text { Count dependent } \\
\text { variable }\end{array}$ & $\begin{array}{c}\text { Model } 4 \\
\text { Count dependent } \\
\text { variable, with } \\
\text { interaction }\end{array}$ \\
\hline Carrot & $-1.584 * *(.613)$ & $-1.422 * *(.613)$ & $-0.883 * *(.421)$ & $-0.754 *(.425)$ \\
\hline Stick & $0.884 * * *(.252)$ & $-0.962(.789)$ & $0.773 * * *(.156)$ & $-0.376(.387)$ \\
\hline Stick* size interaction & & $0.708 * *(.288)$ & & $0.415 * * *(.130)$ \\
\hline Group size & $0.279(.204)$ & $-0.0721(.248)$ & $0.236 * *(.0921)$ & $-0.019(.121)$ \\
\hline Mixed & $0.186(.304)$ & $0.277(.306)$ & $0.413 * *(.169)$ & $0.541 * * *(.173)$ \\
\hline Territory & $0.768 * *(.315)$ & $0.719 * *(.318)$ & $0.403 * * *(.139)$ & $0.336 * *(.142)$ \\
\hline Alliances & $0.164 * * *(.050)$ & $0.162 * * *(.050)$ & $0.080 * * *(.020)$ & $0.083 * * *(.019)$ \\
\hline Rivalry & $0.003 * *(.001)$ & $0.003 * *(.001)$ & $0.001(.000)$ & $0.001(.000)$ \\
\hline Ethnic group & $0.882 * *(.383)$ & $0.881 * *(.381)$ & $0.444 * *(.176)$ & $0.481 * * *(.177)$ \\
\hline Religious group & $0.406(.411)$ & $0.443(.410)$ & $0.174(.182)$ & $0.184(.183)$ \\
\hline Leftist group & $0.508(.484)$ & $0.466(.482)$ & $0.230(.210)$ & $0.170(.212)$ \\
\hline Governing council & $0.338(.491)$ & $0.399(.492)$ & $0.340 *(.196)$ & $0.341 *(.198)$ \\
\hline Single leader & $-0.617(.686)$ & $-0.640(.684)$ & $-0.555(.456)$ & $-0.618(.460)$ \\
\hline Social services & $1.472 * * *(.507)$ & $1.422 * * *(.506)$ & $0.444 * * *(.152)$ & $0.484 * * *(.151)$ \\
\hline Legal political office & $-2.513 * * *(.628)$ & $-2.551 * * *(.638)$ & $-1.488 * * *(.279)$ & $-1.557 * * *(.280)$ \\
\hline Drugs & $0.231(.367)$ & $0.267(.367)$ & $0.331 * *(.151)$ & $0.348 * *(.150)$ \\
\hline Terrorism history & $0.012 * * *(.004)$ & $0.0125 * * *(.004)$ & $0.001 *(.000)$ & $0.001 * *(.000)$ \\
\hline Conflict battle deaths & $0.000 *(.000)$ & $0.000 *(.000)$ & $0.000 * *(.000)$ & $0.000 *(.000)$ \\
\hline State HR violations & $-0.019(.145)$ & $-0.039(.146)$ & $0.050(.074)$ & $0.029(.074)$ \\
\hline State regime type & $0.076(.062)$ & $0.075(.062)$ & $0.039(.030)$ & $0.023(.031)$ \\
\hline State GDPPC (log) & $0.371 * *(.168)$ & $0.382 * *(.168)$ & $0.177 * *(.083)$ & $0.211 * *(.084)$ \\
\hline State population (log) & $0.222 * *(.105)$ & $0.214 * *(.104)$ & $0.056(.046)$ & $.060(.046)$ \\
\hline Group random effects & Yes & Yes & Yes & Yes \\
\hline Year fixed effects & Yes & Yes & Yes & Yes \\
\hline Constant & $\begin{array}{c}-9.542 * * * \\
(2.257)\end{array}$ & $\begin{array}{c}-8.497 * * * \\
(2.271)\end{array}$ & $\begin{array}{c}-5.199 * * * \\
(1.152)\end{array}$ & $\begin{array}{c}-4.597 * * * \\
(1.176)\end{array}$ \\
\hline $\mathrm{N}$ (groups) & $1,240(134)$ & $1,240(134)$ & $1,240(134)$ & $1,240(134)$ \\
\hline
\end{tabular}

Notes: Lead version of dependent variable is used, so essentially all independent variables are lagged one year. Models 1 and 2 are logistic regressions and Models 3 and 4 are negative binomial regressions. ${ }^{*} \mathrm{p}<10,{ }^{* *} \mathrm{p}<.05, * * * \mathrm{p}<.01$ 
Figure

Figure 1. Interaction term in Model 2.

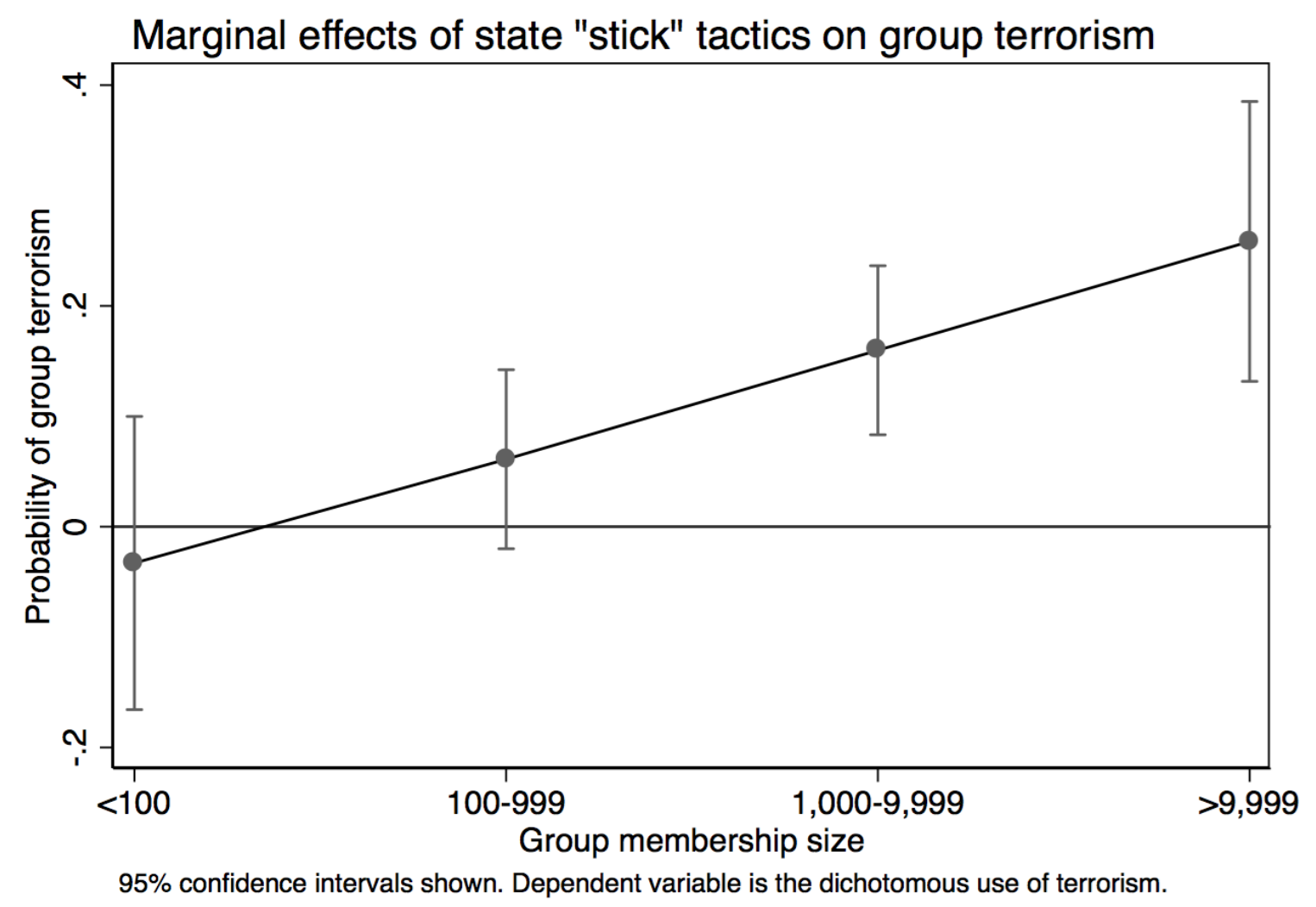




\section{Notes}

${ }^{1}$ See work by Moore $(1998,2000)$ among others that examined the interaction between rebels and states more broadly.

${ }^{2}$ We use "terror," "terrorism," "civilian targeting," and "intentional civilian victimization" synonymously when the perpetrator is a rebel group. There are debates about whether civilian targeting by other actors, such as states, should be referred to as "terrorism," but that is beyond the scope of this manuscript.

${ }^{3}$ See Thomas (2014) as an example in the broader conflict literature. For another important recent exception, see Polo and Gleditsch (2016).

${ }^{4}$ The empirical section shows that these specific state actions are unrelated to state-level characteristics such as regime type or human rights violations generally.

${ }^{5}$ In some ways, this could reward "bad behavior" by the rebel group, as governments may be more likely to offer negotiations to groups that use this terrorism (Thomas 2014). This suggests that conciliatory tactics might reduce terrorism by the targeted group but increase subsequent terrorism from other groups hoping to receive similar treatment or spoil the peace.

${ }^{6}$ Groups outside this process, however, may be more likely to spoil these peace processes (Kydd and Walter 2002, Findley and Young 2015).

${ }^{7}$ Some scholars use the term "repression" as a synonym for state coercive actions, but we usually avoid that term because we are not necessarily referring to human rights violations (a common understanding of repression).

${ }^{8}$ Rasler (1996) suggests that the short-term effect of state repression would be to dampen violence but in the long term, it increases it. Her data are limited to Iran during the 
mobilization against the Shah in the late 1970s. Moore (1998), using new data on different cases, does not find support for this claim.

${ }^{9}$ The data was originally collected beginning in 1998 due to availability of incident-level information and quality of available information. Efforts to extend the dataset to prior years have been hindered by limitations of reliable digitized news articles and government reports.

${ }^{10}$ Previous datasets include some of the same variables. The Non-State Actor Data (NSA) (Cunningham et al 2009) includes information on group size, control of territory, and government support among other variables. However, this dataset is dyadic at the conflict level. For example, in the NSA data there is one coding for Boko Haram. In our dataset there are ten years, from Boko Haram's founding in 2002 until 2012. This provides information on the changes a group undergoes and uniquely allows us to investigate causes and consequences of changes.

${ }^{11}$ If a control variable is included to mark the years that the country is in an intrastate conflict, it is statistically insignificant and other results are robust.

${ }^{12}$ One possibility we looked for is a lack of central leadership. However, given the complexity of size of insurgencies, this leadership type was not used by any of the groups in the dataset.

${ }^{13}$ For example, Al-Qa'ida had a shura council in addition to following Osama Bin Laden and later Ayman al-Zawahiri as the Emir. In this case, since the Emir still retained executive power within the organization and the shura council advised, the group was coded under a hierarchical leadership structure.

${ }^{14}$ Results hold if Al-Qa'ida is excluded. 
${ }^{15}$ Taking temporal dynamics into consideration is important because negotiations might be unlikely at the beginning of a conflict (Bapat 2005).

${ }^{16}$ The appendix includes a model with robust standard errors clustered by group instead of random effects. The stick result holds, but the carrot result does not.

${ }^{17}$ One model instruments for Carrot, Stick, and Mixed with each variable's lagged value, an approach used in many studies. Another model instruments for each of these variables with the mean government use of the tactic (against any group) the previous year. The appendix includes more discussion of the instrumental variable strategy. 